\title{
English proficiency and learner individual differences: A study of pre- service EFL student-teachers
}

\author{
El nivel de competencia en el idioma inglés y las características individuales de los \\ estudiantes de la carrera de docencia en inglés
}

\author{
Mónica Abad $^{1}$ (D), Juanita Argudo ${ }^{1}$ (D), Tammy Fajardo-Dack ${ }^{1}$ (D), Homero Cabrera ${ }^{2}$ (D) \\ 1 Universidad de Cuenca, Av. 12 de abril, Cuenca, Ecuador. \\ 2 AiA Cia.Ltda., Cuenca, Ecuador. \\ Autor para correspondencia: monica.abad@ucuenca.edu.ec \\ Fecha de recepción: 16 de mayo de 2019 - Fecha de aceptación: 13 de junio de 2019
}

\begin{abstract}
This study examines the relationship between individual factors such as age, learning opportunities, and motivation and English language proficiency of pre-service EFL student-teachers. A background questionnaire and an English proficiency test were given to 121 student-teachers. The results revealed that the majority of participants have a low English proficiency which is not likely to improve at the end of the teaching program and that third language learning as well as integrative motivation are strong predictors of language proficiency. Qualitatively, respondents described their reasons for having English language difficulties and for their integrative and instrumental motivation, which complemented the quantitative data. Suggestions for pedagogical practice that might improve the situation are given.
\end{abstract}

Keywords: Pre-service EFL teacher trainees, language proficiency, individual factors.

\section{RESUMEN}

Este estudio examina la relación entre los factores individuales de estudiantes de un profesorado en inglés como la edad, oportunidades de aprendizaje, motivación, y su dominio del idioma extranjero. Un cuestionario de antecedentes y una prueba de dominio del idioma inglés fueron administrados a 121 estudiantes. Los resultados revelaron que la mayoría de participantes tienen un bajo nivel de inglés con pocas probabilidades de mejora al final del programa, y que el aprendizaje de un tercer idioma, así como la motivación integradora, son fuertes predictores de dominio del idioma. Cualitativamente, los participantes describieron las razones que dificultan el aprendizaje del idioma, así como también las de su motivación integradora e instrumental, lo cual complementa los datos cuantitativos. Se sugiere prácticas pedagógicas que podrían mejorar la situación actual.

$\underline{\text { Palabras clave: }}$ Docentes de inglés en formación, nivel de suficiencia de inglés, factores individuales.

\section{INTRODUCTION}

Individual differences when learning a second language are worth researching, not only for their contribution to theory development, but also for their practical implications for language teaching. As Roberts \& Meyer (2012) stated, these differences allow to test hypotheses, especially through the use of correlational studies; similarly, in the words of Lightbown \& Spada (2013), understanding the relationship between cognitive characteristics, personality traits, learning contexts, and success in language learning is of interest to teachers and researchers alike in order to gain a better understanding of second language learning and thus, teach students with different characteristics more efficiently. Among these individual differences, learning speed and the final level of proficiency attained are of particular importance since, if identified beforehand, they could be used to classify learners so that they receive the advice and instruction that suit their needs (Roberts \& Meyer, 2012).
Individual factors are interrelated, and thus, it is very difficult to state that only one factor exerts influence on the speed and success of second language learning (Lightbown \& Spada, 2013); therefore, a variety of cognitive, psychological, social, and strategic variables should be recognized as affecting final proficiency (Moyer, 2004). However, Lightbown \& Spada (2013) suggested that age, motivation and attitude, aptitude, and learning opportunities inside and outside the classroom are of especial importance and thus, should be taken into account to determine its influence on learning rate and final attainment. Likewise, Cook (2008) has pointed out that certain personality traits such as motivation, attitude, aptitude, and age are considered to be highly determinant factors that can stimulate or hinder language learning, while other factors such as cognitive style, intelligence, sex, first language proficiency, and empathy can also influence the learning process, but to a lesser degree.

Regarding age, it is generally believed that the earlier a person starts learning a second language, the better outcome he/she will achieve; however, in the words of 
Lightbown \& Spada (2013), a word of cautious should be stated in this respect, since "starting early is no guarantee of success, and older learners have been able to attain high levels of proficiency in their second language" (p. 96). In fact, there is some controversy about the existence of a critical period for second language acquisition, an age (around puberty) after which successful language acquisition becomes more difficult. Brown (2007) mentions some neurological and phonological based research to endorse the critical period hypothesis but only for the acquisition of a native-like accent, and not for communicative competence or effective interpersonal communication. Nevertheless, according to Patkowsky (1980), when a second language is acquired in a natural environment, native-like mastery of a second language in all areas (not only pronunciation) is limited by age of acquisition. In the same light, Singleton (1989) stated that in natural settings, older learners learn better and faster than children, but the latter surpass the former in the long run. On the other hand, Muñoz (2006) found out that participants who started learning English at the ages of 11, 14, 18 and received the same number of hours of instruction, performed better in tests that measured metalinguistic awareness and analytic ability than the participants who started at the age of 8 and were not surpassed over time by the youngest ones; however, the youngest participants showed advantages on listening performance. It is crucial to acknowledge that the variable age is not the only determinant of second language success and that it has to be analyzed in relation to other variables. In fact, Brown (2007) stated that both children and adults are endowed with the capacity for acquiring a second language at any age and the fact that they do not do it successfully depends on intervening variables such as cognitive, affective, cultural, and contextual; therefore, determining the extent to which these variables affect acquisition is of paramount importance.

An equally significant aspect is motivation, which in relation to second language learning has been defined in terms of communicative needs and attitudes towards the target language and its community (Lightbown \& Spada, 2013); in fact, Gardner (2007) has divided it into two types, integrative and instrumental. The former is related with a willing to understand and participate in the L2 culture so that "the more a student admires the target culture -reads its literature, visits it on holiday, looks for opportunities to practice the language, and so on- the more successful they will be in the L2 classroom;" while the latter refers to practical reasons for language learning, mainly studies, careers, and jobs (Cook 2008, p. 138). As Lightbown \& Spada (2013) noted, both instrumental and integrative motivation are considered predictors for language learning success; however, it is very difficult to determine if learners are successful in second language learning because they are motivated or have a positive attitude, or if it is because they are successful learners that they are motivated and develop a positive attitude, or if other factors that interact with these two are to be blamed, such as aptitude and learning context. Cook (2008) has claimed that foreign language learning in schools may be problematic since the students might lack one or both types of motivation; therefore, the author suggests the use of daily classroom motivation as a key element of instruction. The teacher should be aware that the students' "preconceptions and reservations" about the course, the teacher, the L2 users, and the L2 culture in general affect their learning; therefore, knowing and having those in mind, teachers can devise compelling activities that can influence students' daily motivation and promote successful learning, which can also spawn high motivation. As Lightbown \& Spada (2013) claimed, the teacher's pedagogy can exert an influence on learner's motivation, but there's little research on how this happens. Furthermore, Dörnyei (2001) has asserted that integrative (socially or cultural) and instrumental (academic or career) are not types of motivation but orientations to motivation, which has allowed to identify motivational intensity (high/low) regarding each type of orientation. According to Brown (2007), both types of orientation may affect successful language learning; however, in order to determine the degree of impact of either orientation, it is crucial to consider them as dependent of variables such as "individual learners, educational contexts, cultural milieu, teaching methodology, and social interaction" (p. 185).

Another significant factor is aptitude, whose major components are working memory and the ability to analyze language (Lightbown \& Spada, 2013); in fact, as Ellis (2001) pointed out, working memory can be considered a strong predictor for language learning success in many different learning contexts. Notwithstanding the importance of the variable aptitude to determine success in second language learning, it was not included in this study due to the difficulty to measure working memory storage capacity (Barrouillet \& Gaillard, 2010).

As stated above, the awareness of the relationship between learner's characteristics and language learning success can have a positive impact on EFL teaching in general and all the more so on pre-service EFL teacher education; therefore, in an attempt to contribute with useful insights that might promote the improvement of foreign language teaching and EFL teacher training, the present study addresses the following research question: "To what extent can individual learner characteristics such as age, motivation, and learning opportunities predict language proficiency?"

\section{MATERIALS AND METHODS}

\subsection{Participants and context}

The Faculty of Philosophy of the University of Cuenca in Ecuador, which is a public institution, has offered a major in teaching English as a foreign language since 1977. Students in this major are required to complete a four year undergraduate course (eight levels in eight semesters) during which they take Conversation, Reading and Writing courses; learn linguistic aspects of the English language such as its Grammar, Morphology, Phonetics, Phonology, Syntax, Pragmatics, Etymology, Literature, as well as pedagogical aspects to teach the language such as Teaching theories and methods, Pedagogy, Information Technology, Testing and Evaluation, among others; they are also required to complete 120 hours of supervised practicum. English is used as a medium of instruction in most of the classes, except for the class of Pedagogy, Educational Psychology, Spanish writing, Curriculum, and General Didactics. Due to the fact that the students are not required to take an English proficiency test to register for the program, all the classes are characterized by English mixed-ability students. The participants included a sample of 121 students ( $72.7 \%$ females) registered in the 
fourth (26.4\%), fifth (34.7\%) and seventh semester $(38.8 \%)$. The students taking the other semesters that were offered at the time of the study, this is the first and third semester, were not included in the sample because some of them have a very low English proficiency level. The ages of the participants ranged from 19 to $43(\mathrm{M}=24.11$, $\mathrm{SD}=4.54$ ) and $98.3 \%$ of them had Spanish as their L1, since the majority (97.5\%) were Ecuadorians. In addition, $25 \%$ of them resided in rural areas, $70.2 \%$ had studied in public schools, and $43.8 \%$ had a job, which was related to the teaching field in only $1.7 \%$.

Table 1. Students' profile.

\begin{tabular}{llcc}
\hline Variable & Final value & $\mathrm{N}$ & $\%$ \\
\hline \multirow{2}{*}{ Sex } & Man & 33 & 27.3 \\
& Woman & 88 & 72.7 \\
\hline \multirow{2}{*}{ Semester } & 4th & 32 & 26.4 \\
& 5th & 42 & 34.7 \\
& 7th & 47 & 38.8 \\
\hline \multirow{2}{*}{ Mother } & Spanish & 119 & 98.3 \\
\multirow{2}{*}{ ongue } & English & 1 & 0.8 \\
& Quichua & 1 & 0.8 \\
\hline \multirow{2}{*}{ Area } & Urban & 91 & 75.2 \\
& Rural & 30 & 24.8 \\
\hline \multirow{2}{*}{ Nationality } & Ecuadorian & 118 & 97.5 \\
& Other & 3 & 2.5 \\
\hline \multirow{2}{*}{ Job } & Yes & 53 & 43.8 \\
& No & 68 & 56.2 \\
\hline
\end{tabular}

\subsection{Data collection instruments}

The materials used for this study included a background questionnaire and a proficiency test. Regarding the first instrument, it was designed to inquire about aspects related to age, motivation, and learning opportunities, since they are considered key factors for predicting language learning success (Lightbown \& Spada, 2013). Even though the participants would have been able to complete the questionnaire in English, it was written in Spanish since "the quality of the obtained data increases if the questionnaire is presented in the respondents' mother tongue" (Dörnyei, 2010, p. 49). Due to the exploratory nature of the study, the questionnaire included some specific open questions that asked about personal information (age, mother tongue, nationality, gender, job), past English studies in primary and high school, and extra English courses; some clarification questions that inquired about the reason for some answers; and close ended questions with a five-point scale for the response options that look into the self-evaluation of the use and proficiency of English language. The questions that were categorized as learning opportunities included the number of hours per week of English instruction during primary and high school, extra English courses, and third language studies; while the ones categorized as motivation were divided into instrumental and integrative. Following Cook (2008), instrumental motivation included questions related to their university studies (How many books written in English do you read a year?, How often do you read newspapers and magazines printed in English?, How often do you read digital newspapers and magazines in English?, How often do you speak English in class?, How often do you write in English for academic purposes?, and Why did you choose this major?) while integrative motivation included questions related to attitudes towards the language (since
Dörnyei (1990) stated that integrative motivation was related to general attitudes and stereotypes) and opportunities to practice the language for non-academic purposes (for example, Did you enjoy English classes in primary school and high school?, How often do you read online?, How often do you watch movies, TV, videos?, How often do you speak English outside school?, How often do you write in English for social purposes?, and How important for you is to have a high level of English proficiency?). Finally, some self-evaluation questions (which asked about how the participants evaluated their English proficiency in comparison to that of their classmates and native speakers) as well as those related to the four skills (listening, speaking, reading, writing) that caused the students the most difficulty, were included since, according to Bandura (1997), behaviors and actions can be better predicted through believes rather than real accomplishments.

On the other hand, the proficiency test was taken from the Top Notch/Summit full course placement tests which comprise four sections: listening, reading, general, and speaking tests. This instrument was selected since it purports to place students accurately within the Top Notch/Summit series and to serve as a "quick diagnostic inventory of each student's relative abilities" (Saslow \& Ascher, 2006, p. VII); in addition, it allows to calculate students' placement without considering the speaking test, which was very useful for this study since it was not feasible to interview every participant. The listening and reading tests include 10 multiple-choice questions of increasing difficulty each, while the general test consists of 120 multiple-choice items that test knowledge of vocabulary, grammar, and social language; therefore, the whole test includes 140 questions. After doing all, the calculations suggested in the manual to place every participant in one of the six levels of the Top Notch and Summit course; the correspondent level within the Common European Framework of Reference (CEFR) was determined based on the information provided on each of the six books of this course; for instance, the book Top Notch 1 claims that students will reach an A1 level after completion of the book; therefore, if students were placed in Top Notch 1 (meaning that they have to take this level), it was assumed that they had a lower level than A1.

\subsection{Data analysis procedure}

The software package SPSS22 was used to calculate descriptive statistics such as frequencies (n) and percentages $(\%)$ as well as to run the KolmogorovSmirnov nonparametric test, which tested the normality of the distribution; the ANOVA test (F) and the Pearson Correlation Coefficient test (r), which measured the association between sociodemographic variables and English performance level. In addition, Eta-squared was used to measure the Effect Size (ES), in other words, the strength of the association when the ANOVA test was used. If the result of Eta-squared shows a value $\leq .04$, it is considered that the ES is small; if the result shows a value $.04<$ to $\leq .36$, the ES is medium, but if it is $>.36$, it is large. To measure the Effect Size of Pearson Correlation, the correlation coefficient was considered; therefore, if the coefficient is around .10, the ES is small, if it is around .30, the ES is medium, but if it is around .50, the ES is considered large (Cohen, 1992). The significance level was established at $\mathrm{p}<0.05$, in other words, an association between the English performance level and a 
sociodemographic variable was considered only if the probability value was less than 0.05 . The significant correlated variables were included in a multiple linear regression analysis $\left(\mathrm{R}^{2}\right)$ only when they better fit the regression model, which determined the predictability of the variables age, learning opportunities (number of hours of instructions in primary school and third language learning), and motivation (watch movies, videos, and TV in English and speak English outside classroom) in relation to the English proficiency.

For the analysis of the clarification questions, a content analysis was carried out by three members of the research team, who identified key points which were later placed into broader categories. Any disagreement was resolved by ensuing discussions among the research team. The frequency of each category was considered as a descriptive element that generated evidence to know the reasons why the participants enjoyed or did not enjoy English classes in primary school and high school, why they considered that having a high level of English proficiency was important, why they chose the English teaching major, and the problems they had when speaking and listening.

\section{RESULTS}

Regarding to the English classes in primary and high school (Table 2), 38\% of the participants indicated that they did not take any classes during primary school, $19 \%$ did not enjoy the classes in primary school, and $27.3 \%$ stated that they did not enjoy English classes in high school. When asked about the reason why they enjoyed their English classes, most of the participants mentioned their interest in learning the language because they liked the sound of it, the pronunciation, English songs and wanted to communicate with foreigners; another reason that stood out was that the classes were entertaining, interesting, engaging, and active, and finally, the last common reason was the material used in class such as videos, movies, songs, and games. On the other hand, the participants who disliked the classes indicated that the activities were repetitive, boring, monotonous, not practical, and unchallenging since the contents were repeated in most levels; another important reason was that they did not understand anything, and finally, they mentioned that the teachers did not plan their classes, had terrible pronunciation, spoke Spanish most of the time, only read the textbooks, were not active, were very strict and bad tempered. On average, the participants had attended 2.68 hours of English classes per week in primary school (in a range from 0 to 10 hours a week, SD 2.27), while in high school 4.89 hours a week (SD 4.89, in a range from 1 to 12 hours a week). Regarding extra English classes, $38 \%$ had taken them in the past while only $4.1 \%$ were taking them at the time of this study. In addition, $19.8 \%$ had studied or were studying a third language, $6.6 \%$ had studied English in an English-speaking country while $8.1 \%$ had lived in such a country.

Moreover, the participants' main reasons for having decided to become English teachers were (1) their fondness for the English language, (2) their desire to share knowledge and help other people learn English, (3) the possibility of getting a better job since the knowledge of English opens doors and has become a necessity nowadays, (4) the desire to communicate and understand people from other cultures, (5) the desire to improve and master the English language, and (6) the desire to travel around the world. In addition, there were few participants who stated that they had to choose this major because it was the only opportunity to be able to enter university since they did not obtain a good enough score in the SNNA exam (which is an exam that high schools students in Ecuador need to take if they are interested in studying in a public university).

Regarding reading habits in English (Table 3), the participants indicated they read 4 to 6 books a year (which comes from the mean 2.26, SD 0.74), they almost never read magazines and newspapers printed in English (mean 2.45, SD 1.01), but almost always when this same material was digital (mean 3.11, SD 0.97), and they almost always read online (mean 3.94, SD 0.89). With respect to listening in English, they almost always watched movies, TV, and videos (mean 3.71, SD 0.85). Concerning speaking in English, they almost always speak English in their classes (mean 3.76, SD 0.85), but sometimes when they are outside college (mean 2.69, SD 0.91). Finally, in relation to the writing skill, they almost always write for academic purposes (mean 3.93, SD 1.02), but sometimes for social purposes (mean 2.64, SD 0.97).

With respect to the self-evaluation of English proficiency, the participants indicated that, comparing with their classmates, their English level was good (mean 3.21, SD 0.85 ), but in comparison to native speakers, they said it was less than average (mean 2.55. SD 0.90). For almost all of them, having a high level of English proficiency is very important (mean 4.88, SD 0.32). As regards the reason why having a high level of English proficiency was important to the participants, the most stated reason was that for being EFL teachers, a very good/perfect English is required; another reason that stood out was that since English is an international language, it is a necessity not only as a tool for learning, but also for getting better jobs in general; lastly, some students mentioned the importance of communicating with people from other countries and cultures.

The results of the English proficiency test indicate that the participants' level of English ranged between A1 minus to C1. Only $10.7 \%$ reached a B2 level, which is the requirement to be able to teach in Ecuadorian schools and high schools (Ministerio de Educación, n.d.). On average, the participants' mean score was 69.41 (SD 20.53) in a range from 23 to 120 .

It is important to mention that when asked about which of the four skills (reading, writing, listening, speaking) caused them the most difficulty, $42.1 \%$ of the participants indicated speaking while $39.7 \%$, listening; only $5 \%$ and $13.2 \%$ indicated reading and writing respectively. Pertaining the reason for the most difficult skill, the ones who indicated Speaking stated that the major problem was pronunciation, but they additionally mentioned lack of vocabulary and fear of making mistakes, being embarrassed, or being laughed at by their classmates. Similarly, the participants who considered Listening as the most difficult skill pointed out that pronunciation problems and lack of vocabulary were the main cause for comprehension difficulties, but they also mentioned difficulty to separate words, to understand some accents, and to understand fast speech. 
Table 2. Students' background.

\begin{tabular}{|c|c|c|c|c|c|}
\hline Variable & Final value & $\mathrm{N}$ & $\%$ & Mean & SD \\
\hline \multirow{3}{*}{ Enjoyed classes primary school } & Yes & 52 & 43 & & \\
\hline & No & 23 & 19 & & \\
\hline & Did not take any & 46 & 38 & & \\
\hline \multirow{2}{*}{ Enjoyed classes high school } & Yes & 88 & 72.7 & & \\
\hline & No & 33 & 27.3 & & \\
\hline \multirow{2}{*}{ Third language } & Yes & 24 & 19.8 & & \\
\hline & No & 97 & 80.2 & & \\
\hline \multirow{2}{*}{ English speaking country } & Studied & 8 & 6.6 & & \\
\hline & Lived & 10 & 8.1 & & \\
\hline Number of weekly hours in prim & & 121 & 100 & 2.68 & 2.27 \\
\hline Number of weekly hours in high & & 121 & 100 & 4.89 & 4.89 \\
\hline
\end{tabular}

Table 3. Students' self-evaluation.

\begin{tabular}{lccccc}
\hline \multicolumn{1}{c}{ Variable } & $\mathrm{N}$ & Mean & SD & Min & Max \\
\hline Read books $^{\mathrm{a}}$ & 121 & 2.26 & 0.74 & 1 & 4 \\
Read printed magazines or newspapers $^{\mathrm{b}}$ & 121 & 2.45 & 1.01 & 1 & 5 \\
Read digital magazines or newspapers $^{\mathrm{b}}$ & 121 & 3.11 & 0.97 & 1 & 5 \\
Read online $^{\mathrm{b}}$ & 121 & 3.94 & 0.89 & 1 & 5 \\
Watch movies, videos, TV $^{\mathrm{b}}$ & 121 & 3.71 & 0.85 & 1 & 5 \\
Speak English in class $^{\mathrm{b}}$ & 121 & 3.76 & 0.85 & 1 & 4 \\
Speak English outside classs $^{\mathrm{b}}$ & 121 & 2.69 & 0.91 & 1 & 5 \\
Write in English for academic purposes $^{\mathrm{b}}$ & 121 & 3.93 & 1.02 & 1 & 5 \\
Write in English for social purposes $^{\mathrm{b}}$ & 121 & 2.64 & 0.97 & 1 & 5 \\
Self-evaluation of English level in comparison to classmates $^{\mathrm{c}}$ & 121 & 3.21 & 0.85 & 1 & 5 \\
Self-evaluation of English in comparison to native speakers $^{\mathrm{c}}$ & 121 & 2.55 & 0.90 & 1 & 5 \\
Importance of having high proficiency $^{\mathrm{d}}$ & 121 & 4.88 & 0.32 & 1 & 2 \\
\hline
\end{tabular}
$\mathrm{a}=0$ (1) / 1-3 (2) / 4-6 (3) / 6-12(4) books

$\mathrm{b}=$ Always (5) / Almost always (4) / Sometimes (3) / Hardly ever (2) / Never (1)

$\mathrm{c}=$ Excellent (5) / Very good (4) / Good (3) / Not really good (2) / Terrible (1)

$\mathrm{d}=$ Very important (5) / Important (4) / Somewhat important (3) / A little bit important (2) / Not important (1)

Relating the scores obtained in the proficiency test to the sociodemographic variables, it was found that the students in the fourth semester reached the highest score (75.31) while the ones in the seventh semester the lowest (63.98); the Eta-squared shows a moderate Effect Size (.052). A post-hoc analysis indicated that these differences were statistically significant; however, the fifth semester students score (71.00) do not show any significant differences with the other two groups. In addition, even though the differences of the scores between the students who studied in private and public schools was not statistically significant, it can be seen that the students from private schools had a higher mean. Furthermore, a statistically significant difference was found with the variable enjoyment of English classes in primary school, that is, the participants who enjoyed the English classes obtained higher scores (76.69) in the proficiency test than the ones who did not have English classes (64.17) or the ones who did not enjoy the classes (63.44); the Etasquared shows a moderate Effect Size (.096). On the other hand, the variable enjoyment of English classes in high school was not significant different. The most statistically significant difference was found with the participants who had studied or were studying a third language, obtaining the highest score (82.58); the Eta-squared shows a moderate Effect Size (.103) as it is showed in Table 5.

Another important finding is the one related to the variable age, that is, the younger the participants, the better their English proficiency level (a correlation of $-32 \%$ ), which is considered a medium Effect Size. Not surprisingly, it can also be seen that the number of hours of instruction in primary or in high school correlates with the proficiency level ( $49 \%$ and $44 \%$, respectively), which is considered a large Effect Size. Other important correlations were found with the variables reading online (35\%), which is a medium Effect Size, watch movies, TV, videos (33\%, medium Effect Size); speaking English in class (32\%, medium Effect Size), speaking English outside class (31\%, medium Effect Size), and writing in English for social purposes (23\%, small Effect Size). Likewise, selfevaluating their English level in relation to their classmates' level (38\%, medium Effect Size) and in relation to native speakers (39\%, medium Effect Size) presented a significant correlation (see Table 6).

Associated variables as well as significant correlated ones were included in a multiple linear regression model; however, only six variables comprised the model: 1) age, 2) number of hours in primary school, 3) number of hours in high school, 4) third language learning, 5) watch movies, videos, and TV, and 6) speak English outside classroom. These variables are considered predictors in a .388 (Adjusted R Square). The properties of the model suggest a significant ANOVA ( $F=13.700,6$ gl, sig. .000).

It can be seen that the variables age, learning opportunities (number of hours of English instruction in school and the study of a third language), and integrative motivation (watch movies, videos, or TV; and speak English outside 
classroom) are predictors of the participants' English proficiency. In fact, for every decrease in age of one-year, English proficiency increases 0.86 ; for every hour increase in primary and high school English instruction, English proficiency increases 1.91 and 2.18 respectively. Learning a third language produces a stronger prediction since English proficiency raises in 8.32. In addition, watching movies, videos, and TV lead to an English proficiency level of 3.87. Finally, speaking English outside the classroom increases English proficiency in 3.92.
Table 4. Descriptive results.

\begin{tabular}{lcccccc}
\hline Level & N & $\%$ & Mean & SD & Min & Max \\
\hline A1- & 3 & 2.5 & & & & \\
A1 & 27 & 22.3 & & & & \\
A2 & 36 & 29.8 & 69.41 & 20.54 & 23 & 120 \\
B1 & 40 & 33.1 & & & & \\
B2 & 13 & 10.7 & & & & \\
C1 & 2 & 1.7 & & & & \\
\hline
\end{tabular}

Table 5. English proficiency related to profile and background.

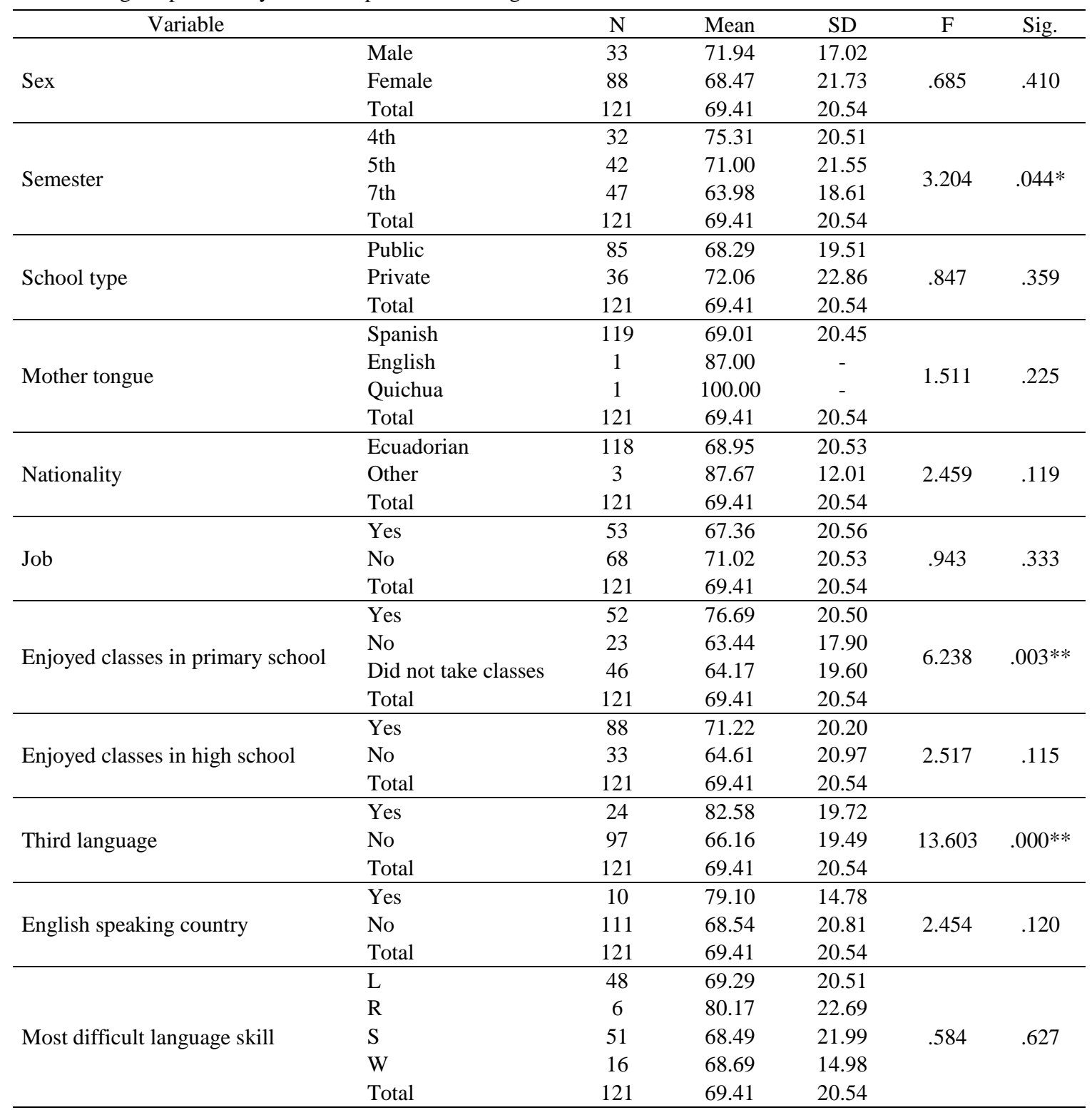

Therefore, it can be said that age and number of hours of instruction support the model less than Third language learning, and integrative motivation. It is important to mention that the variables categorized as instrumental motivation, which are activities that are usually required on an academic setting, do not allow to establish any prediction.

\section{DISCUSSION}

The purpose of this study was to identify the background and individual learner characteristics (age, motivation, perceptions, and learning opportunities) as well as their relationship with the English proficiency level of participants who are being prepared to become EFL teachers. Based on the results, it can be said that the majority of the participants come from public schools in 
which the number of hours of English instruction offered to students is less than half in comparison to those from private schools. Some of them (38\%) did not take any English classes during the 6 years of primary education, while only few of them did not enjoy English classes in primary school and high school (19\% and 27.3\%, respectively). Some participants $(38 \%)$ had taken extra English classes while a very small proportion (4.1\%) were taking them at the time of the study. In addition, a very small proportion of the participants (19.8\%) had studied or were studying a third language. It is not surprising that the majority of students come from public educational institutions since the University of Cuenca is also a public one and thus, requires no tuition payment. In addition, based on the proficiency test scores, it is very likely that students with very low levels of proficiency (A1-) share a class with students with high levels (C1), which might be a predicament for the teachers when planning lessons due to the very different language needs of these students. In fact, the results show that the majority of students reached an A1 and A2 level, which is a little alarming since in the curriculum project of the English teaching program, it is stated that at the end of their studies, the students will have reached a B2 or C1 level (Plan de la Carrera, 2013). However, it is very unlikely that seventh level students with $\mathrm{A} 1, \mathrm{~A} 2$, or even $\mathrm{B} 1$ reach a $\mathrm{B} 2$ level, let alone a $\mathrm{C} 1$, because, as it is indicated in the CEFR, it takes around 250 hours of instruction on grammar, vocabulary, and the four language skills (listening, speaking, reading and writing) to pass from B1 to B2 (Council of Europe, 2011). It seems that the three semesters of receiving grammar, conversation, reading and writing instruction do not help students who start at a very low level to reach a B2 level. In addition, taking subjects in English appears to be not enough to improve the students' language development unless a focus on both content and language takes place; as a matter of fact, when teaching subjects in a second language, it cannot be assumed that learners have the necessary subject-specific language skills, let alone that they will pick them up eventually without being taught (Ball, Kelly and Clegg, 2015). A practical solution will be the requirement of an A2 or B1 level language certificate to be able to register for the teaching program; however, if this measure was in place, only very few students would be able to fulfill the requirements; therefore, the teaching program would not be started due to the insufficient number of students. Since there is a necessity for primary and high school English language teachers in Cuenca, this solution is not viable; therefore, the challenge resides in finding mechanisms to help these low proficient students who are interested in becoming English teachers to develop their language skills to a B2 level.

In addition, the results indicate that the most difficult skills for the participants are speaking and listening, which is not surprising since these two skills depend on each other and the development of the listening skill is essential for the development of speaking (Rost, 2001). According to Oxford (2017, p. 289), "although people often think that L2 speaking is the most difficult skill of all, L2 listening is as difficult as speaking because it often requires splitsecond comprehension followed by an expectation of a meaningful response." Moreover, it seems that teachers do not give listening the necessary attention and expect learners to develop it by themselves (Field, 2008; Vandergrift \& Goh, 2012). Regarding the reasons for their difficulty, the participants stated that pronunciation and lack of vocabulary were what they blamed the most for both their speaking and listening difficulties, which is in agreement to the idea that "speaking cannot be understood without phonology, pronunciation, and pragmatics" (Oxford, 2017, p. 289) and that "vocabulary is a core component of language proficiency and provides much of the basis for how well learners speak, listen, read, and write" (Richards \& Renandya, 2002, p. 255). Furthermore, in relation to the speaking skill, the participants also mentioned that the fear of embarrassment when making mistakes was another important problem that refrained them from speaking; this problem was acknowledge by Ur (1995), who among other problems, stated that fear of making mistakes, losing face, criticism, and shyness are likely to occur in language classrooms. On the other hand, regarding listening skills, besides the most important reasons mentioned above, the participants stated that they have problems to separate words, to understand some accents, and to understand fast speech, which is in line with Goh (2000) and Hasan (2000) who also found these problems among others.

Table 6. English proficiency correlated to ordinal variables.

\begin{tabular}{|c|c|c|}
\hline Variable $^{\mathrm{a}}$ & Pearson's $r$ & Significance \\
\hline Age & $-.320 * *$ & 0 \\
\hline $\begin{array}{l}\text { Number of hours a week } \\
\text { in primary school }\end{array}$ & $.489 * *$ & 0 \\
\hline $\begin{array}{l}\text { Number of hours a week } \\
\text { in high school }\end{array}$ & $.444 * *$ & 0 \\
\hline Read books in English & -0.1 & 0.276 \\
\hline $\begin{array}{l}\text { Read printed magazines } \\
\text { and newspapers }\end{array}$ & 0.009 & 0.922 \\
\hline $\begin{array}{l}\text { Read digital magazines } \\
\text { and newspapers }\end{array}$ & 0.15 & 0.101 \\
\hline Read online & $.345 * *$ & 0 \\
\hline $\begin{array}{l}\text { Watch movies, videos, } \\
\text { and TV }\end{array}$ & $.331 * *$ & 0 \\
\hline $\begin{array}{l}\text { Speak English in the } \\
\text { classroom }\end{array}$ & $.321 * *$ & 0 \\
\hline $\begin{array}{l}\text { Speak English outside } \\
\text { classroom }\end{array}$ & $.310 * *$ & 0.001 \\
\hline $\begin{array}{l}\text { Write in English for } \\
\text { academic reasons }\end{array}$ & 0.05 & 0.585 \\
\hline $\begin{array}{l}\text { Write in English for } \\
\text { social reasons }\end{array}$ & $.230 *$ & 0.011 \\
\hline $\begin{array}{l}\text { Self-evaluate English } \\
\text { proficiency in relation to } \\
\text { their classmates }\end{array}$ & $.382 * *$ & 0 \\
\hline $\begin{array}{l}\text { Self-evaluate English } \\
\text { proficiency in relation to } \\
\text { native speakers }\end{array}$ & $.385 * *$ & 0 \\
\hline $\begin{array}{l}\text { Importance of having } \\
\text { high English proficiency }\end{array}$ & $.183^{*}$ & 0.045 \\
\hline
\end{tabular}

The results also indicate a significant inverse correlation with the variable age, meaning that the younger the students, the better results they had on the proficiency test, which was also supported by the significant correlation found with the variable level of instruction, that is, the fourth level students who are younger ( 23 years old) got much better results than the seventh level ones ( 25 years old); however, the correlation with the fifth level students 
was not significant, which highlights the importance of considering the variable age in relation to other factors instead of taking it as the only predictor for language proficiency (Lightbown \& Spada, 2013).

Table 7. Multiple lineal regression of English proficiency related to age, learning opportunities and motivation.

\begin{tabular}{|c|c|c|c|c|c|c|}
\hline \multirow[t]{2}{*}{ Model } & & \multicolumn{2}{|c|}{ Unstandardized coefficients } & \multirow{2}{*}{$\begin{array}{c}\text { Standardized } \\
\text { coefficients }\end{array}$} & \multirow[t]{2}{*}{$\mathrm{t}$} & \multirow[t]{2}{*}{ Sig. } \\
\hline & & B & Std. Error & & & \\
\hline Constant & & 111.127 & 13.488 & & 8.239 & .000 \\
\hline Age & Age in years & -0.856 & 0.354 & -0.188 & -2.420 & .017 \\
\hline \multirow{3}{*}{$\begin{array}{l}\text { Learning } \\
\text { opportunities }\end{array}$} & Number of hours in primary school & 1.914 & 0.847 & 0.212 & 2.261 & .026 \\
\hline & Number of hours in high school & 2.178 & 0.882 & 0.216 & 2.470 & .015 \\
\hline & Third language & 8.315 & 3.985 & 0.162 & 2.086 & .039 \\
\hline \multirow{2}{*}{ Motivation } & Watch movies, videos, and TV & 3.874 & 1.950 & 0.161 & 1.987 & .049 \\
\hline & Speak English outside classroom & 3.916 & 1.762 & 0.174 & 2.223 & .028 \\
\hline
\end{tabular}

Two other variables (third language learning and length of instruction) which were categorized as learning opportunities had a significant correlation with the English proficiency level. For instance, the students who had studied or were studying a third language obtained the highest scores on the proficiency test. These results are in line with Griessler (2001) who found positive effects of a third language on second language proficiency and thus, supported the cross-linguistic influence hypothesis which states that any language influences the acquisition or learning of another. Another significant correlation was found with the variable length of instruction, that is, the students who had the opportunity to attend more English classes got a higher score in the proficiency test, which endorses the idea that "one or two hours a week will not produce advanced second language speakers, no matter how young they were when they began" (Lightbown \& Spada, 2013, p. 98).

Regarding the variables categorized as instrumental motivation, only speaking English inside the classroom had a significant correlation with the English proficiency level while most of the variables categorized as integrative motivation (that is enjoyment of English classes in primary school, online reading, TV, movie, and video watching; speaking English outside the classroom; and writing for social purposes) were significantly correlated to the English proficiency level. These results are in accordance with Cook (2008) who, in her studies done in different countries, found that integrative motivation was more important than instrumental motivation, which means that "people want to learn a language for getting on with people more than they do for job opportunities" (p. 138), which is endorsed in this study since the variable speaking English outside the classroom is the strongest predictor of language proficiency. However, Brown (2008) pointed out that the instrumental and integrative orientation depends on the context in which a second language is learned, that is, in certain contexts, leaners tend to be more successful in learning a second language if they have an integrative orientation, while in other contexts, their success will depend more on an instrumental orientation, since integrative and instrumental orientations are not mutually exclusive, and thus, most learning situations involve both types of orientations.

\section{CONCLUSIONS}

The results suggest that the majority of students who want to become English teachers enter the University of Cuenca with a low proficiency level which does not improve enough to reach the required level (B2) for teaching English in Ecuadorian schools. Therefore, it is imperative to take action to ensure high quality English teaching in these schools; this can be done by trying methodologies that are said to foster language development. One such methodology, for example, could be CLIL (content and language integrated learning) because it focuses on developing both content and language equally; this way, the pre-service EFL trainees' instructors would not only be responsible of students' subject knowledge but also of their language development. The chosen methodology should emphasize the instruction of speaking and listening skills as well as vocabulary and pronunciation. Furthermore, it would be advisable that students learn a third language at some point of the teaching program, for instance, when they have already reached an intermediate English level since it might greatly contribute to their English language development. Finally, even though the results show that integrative motivation is more important than instrumental motivation, the instrumental reasons given by the participants in relation to the importance of having a high level of English proficiency (since the most stated reasons were related to their careers as English teachers and to get better jobs in general) and the mixture of instrumental and integrative reasons for having decided to become English teachers show the presence of both types of orientations. Nevertheless, making students speak English outside the classroom as well as watch movies, videos, or TV in English cannot be overemphasized if English proficiency is to improve.

Based on the results of this study, which was exploratory in nature, more research could be done to deeply understand the influence that age, motivation, and learning opportunities have on language learning; moreover, it would be advisable to include the aptitude factor in order to gain better insights. 


\section{REFERENCES}

Ball, P., Kelly, K., \& Clegg, J. (2015). Putting CLIL into Practice. United Kingdom: Oxford University Press.

Bandura, A. (1997). Self-efficacy: The exercise of control. New York: Freeman.

Barrouillet, P. \& Gaillard, V. (2010). Cognitive development and working memory: A dialogue between Neo-Piagetian theories and cognitive approaches. New York: Psychology Press.

Brown, D. (2007). Principles of language learning and teaching $\left(5^{\text {th }}\right.$ ed). New York: Pearson Education.

Cohen, J. (1992). A power primer. Psychological Bulletin, 112(1), 155-159.

Cook, V. (2008). Second language learning and language teaching $\left(4^{\text {th }}\right.$ ed.). London, Great Britain: Hodder Education.

Dörnyei, Z. (1990). Conceptualizing motivation in foreign-language learning. Language Learning, 40(1), 45-78.

Dörnyei, Z. (2001). Motivational strategies in the language classroom. London: Cambridge University Press.

Dörnyei, Z. (2010). Questionnaires in second language research: Construction, administration, and processing $\left(2^{\text {nd }}\right.$ ed.). New York, NY: Routledge.

Ellis, N. C. (2001). Memory for Language in P. Robinson (Ed.): Cognition and Second Language Instruction (pp. 33-68). London: Cambridge University Press.

Field, J. (2008). Listening in the Language Classroom. Retrieved from

http://ebooks.cambridge.org.myaccess.library.utoronto. ca/ebook.jsf?bid=CBO9780511575945

Gardner, R.C., (2007). Motivation and second language acquisition. Porta Linguarum, 8, 9-20.

Goh, C. (2000). A cognitive perspective on language learners' listening comprehension problems. System, 28, $55-75$.

Griessler, M. (2001). The effects of third language learning on second language proficiency: An Austrian example. International Journal of Bilingual Education and Bilingualism, 4(1), 50-60. doi:10.1080/13670050108667718

Hasan, A. (2000). Learners' perceptions of listening comprehension problems. Language, Culture and Curriculum, 13, 137-153.

Hasan, A. (2000). Learners' perceptions of listening comprehension problems. Language, Culture and Curriculum, 13, 137-153.
Lightbown, P. and Spada N. (2013). How languages are learned. United Kingdom: Oxford University Press.

Moyer, A. (2004). Age, accent, and experience in second language acquisition. Clevedon, UK: Multilingual matters.

Ministerio de Educación (n.d). Anuncio para docentes elegibles de inglés. In Fortalecimiento del inglés. Retrieved from https://educacion.gob.ec/anuncioimportante-para-los-candidatos-elegibles-que-aspirana-un-nombramiento-como-docentes-de-ingles/

Muñoz, C. (2006). The effects of age on foreign language learning. The BAF project. In C. Muñoz (Ed.) Age and the Rate of Foreign language learning. Clevedon, UK: Multilingual Matters Ltd., pp 1-40.

Oxford, R. (2017). Teaching and researching language learning strategies: Self-regulation in context. New York, NY: Routledge.

Patkowsky, M. (1980). The sensitive period for the acquisition of syntax in a second language. Language Learning, 30(2), 449-472.

Plan de la Carrera de Ciencias de la Educación en la especialización de lengua y literatura inglesa (2013).

Richards, J. C., \& Renandya, W. A. (Eds.). (2002). Methodology in language teaching: An anthology of current practice. Cambridge: Cambridge University Press.

Roberts, L. \& Meyer, A. (2012). Individual differences in second language learning: Introduction. Language Learning, 62, 1-4. doi:10.1111/j.14679922.2012.00703.x

Rost, M. (2001). Listening. In Carter, R. \& Nunan, D. (Eds.), The Cambridge Guide to Teaching English to Speakers of Other Languages. Retrieved from http://ebooks.cambridge.org.myaccess.library.utoronto. ca/ebook.jsf?bid=CBO9780511667206

Saslow, J. \& Ascher, A. (2006). Top notch/ Summit fullcourse placement tests. New York, NY: Pearson Education.

Singleton, D. (1989). Language acquisition: The age factor. Clevedon, Avon: Multilingual Matters.

Ur, P., 1995. A course in language teaching. Practice and theory. Cambridge, UK: Cambridge University Press.

Vandergrift, L., \& Goh, C. (2012). Teaching and learning second language listening: Metacognition in action. New York, NY: Routledge. 